\title{
ヘリコプタ・ブレードのための動的制振器の解析* Analysis of a Dynamic Vibration Absorber for Helicopter Blades
}

\author{
山本雄 三**.安東茂典**. 石垣裕嗣*** \\ Yuzo Yamamoto, Shigenori Ando and Hiroshi Ishigaki
}

\begin{abstract}
An analysis is presented for the Frahm-type blade-vibration-absorber (BVA) when the second flapwise bending natural circular frequency $\left(\omega_{2}\right)$ coincides with the three per revolution $(3 \Omega)$. The rate of change in $\omega_{2}$ with increasing the mass of BVA is drastic for the smaller mass ratio, but becomes mild for the larger one. For the purpose of comparison, the effect of a simply fixed weight is also investigated. The effect of BVA is much larger than that of the fixed weight for a same mass ratio in the both devices, if the mass ratio is reasonably small and if the station does not coincides with modal shape nodes.
\end{abstract}

\section{1. 序論}

ヘリコプタ・ロータ・ブレードの回転中の固有円振 動数のいくつかは，しばしば常用回転角速度の整数倍 と一致する. 一方ロータ・ブレードに作用する多くの 力のなかには，種々の原因で回転数の整数倍の周期を あつものがある，そのため，減衰(たとえば空気力の) が十分でなりれば，許容され得ないほどの振動レベル となる，とのような場合，固有振動数を僅かにずらせ ることが非常に効果的である.

文献 4) には，フラッピングの固有振動数を変える ための振子型の一装置の写真が揭載されている，また 文献 3) には本装置 (“BVA”) の效果が報告されてい る. 筆者の 1 人がこの装置を知ったのはヒューズ・ヘ リコプタ OH-6A を見たときである. しかしヒュー ズ社加ら本装置設計のための解析資料は入手されなか ったので，“FRAHM の動吸振器”2) に属するおのと推 定しその解析方法を考案した.

その後他の 2 人がこれのディジィタル・コンピュー タによる数值計算法を工夫し，本報告書内に示すよう な成果を得た。

計算に際しては簡単のために，ロータ・ブレードは 回転軸にリジッドに取りつけられた一様断面の片持ば りである，と仮定した. しかしてれらの仮定は本解析 法の適用範囲を本質的に制限するものではない.

\footnotetext{
*昭和 47 年 12 月 8 日 原稿受理

** 名古屋大学工学部航空学科

*** 日立造船株式会社
}

2 次の固有円振動数之, 回転角速度の3 倍が一致す る場合について検討した。 また振子の効果が卓越して いることを示すために，単純付加質量についても計算 した.

解析方法としては，既存の HOLZER-MYKLESTADLEONE ${ }^{11}$ の方法を修正したすのを用いた。

本報告で作製し使用した計算プログラムは僅かな修 正によって非一様な実際のロータ・ブレードにあ使用 できる.

\section{2. 主な 記 号}

$A:$ 棒 (ブレード) の断面積

$E I:$ 棒の曲げ剛性

$f_{x}:$ 分布荷重の $x$ 方向成分

$f_{z}:$ 分布荷重の $z$ 方向成分

$f_{\text {口व口: }}$ 式(19)で定義される.

$g:$ 重力の加速度

$\boldsymbol{i}, \boldsymbol{j}, \boldsymbol{k}$ : 回転座標軸 $x, y, z$ 方向の単位ベクトル

$l_{t}:$ 棒の全長

$l_{j}:$ 棒の要素の長さ

$l_{w}:$ 振動数制御用振子の長さ

$m_{t}:$ 棒の全質量

$m_{j}:$ 棒の分割点に集中された質量

$m_{w}$ : 振子の質量

$M$ : 曲げモーメント

$n:$ 棒の分割数

$p_{m}=m_{\mathrm{tw}} / m_{\mathrm{t}}$

$p_{t}=l_{\text {to }} / l_{t}$

$\boldsymbol{r}=$ 位置ベクトル

$S=$ 剪断力

$T=$ 運動エネルギ

$t=$ 時間

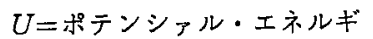

$V_{\alpha S_{j}}, V_{\alpha M j}, V_{z M j}, V_{x} s_{j}, D_{z S_{j}}, D_{z M j}:$ 影響係数

$x=$ 回転軸からの，棒に沿うた距離

$x_{k}, z_{k}=$ 振子取りつけ位置

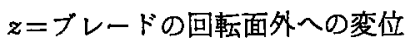

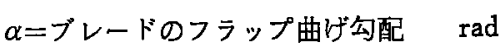

$\theta$ : 振子の鉊直面加らの傾き $\mathrm{rad}$

$\rho:$ 棒の質量密度 


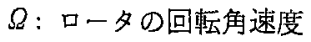

$$
\begin{aligned}
& \omega \text { : 系の固有円振動数 } \\
& \omega^{\prime} \text { : 同上ただし付加物があるとき } \\
& \omega_{w} \text { : 振子の非連成固有円振動数 } \\
& \Psi: \text { ブレードの方位角 } \\
& \delta: \text { ブレード先端における変位 } \\
& \varphi: \text { ブレード先端の傾斜角 } \\
& \text { その他 } \\
& \left.\begin{array}{l}
\tilde{x}=x / l_{t} \\
\tilde{\Omega}=\Omega / \sqrt{E I / m_{t} l_{t}{ }^{3}} \\
\tilde{\omega}=\omega / \sqrt{E I / m_{t} l t^{3}}
\end{array}\right\} \text { 無次元 } \\
& \text { ( ) : 複素振幅 } \\
& i: e^{i \omega t} \text { として現われたむのはV } \overline{-1} \text { ，るうでない }
\end{aligned}
$$

場合には第 $i$ 番目の分割 station を表わす.

\section{Holzer-Myklestad-Lene の方法}

本報告で用いられる理論は振子をもつ場合 文献 1) のそれを应張したあのである. 文献 1) の方法はHolzer-Myklestad 法の系統に属するから Holzer-Myklestad-Leone(HML) 法と以下略称する. しかし文献 1) で用いられた記号は体系的に整理されていず，憶えに くい，それで本論文では，まずこの点を改善するため に，全面的に書き直すことにする*.

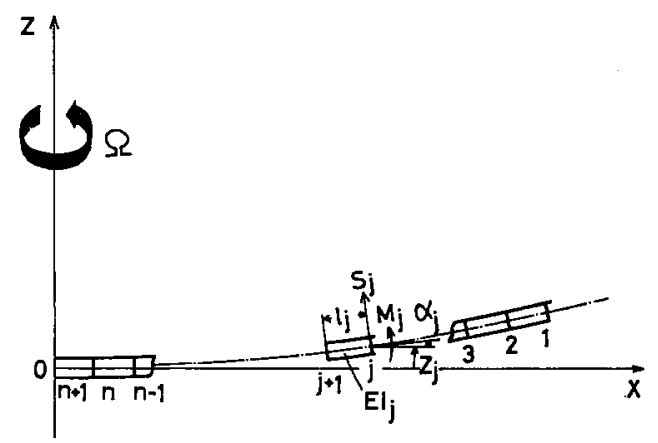

第 1 図 溙の分制と座標

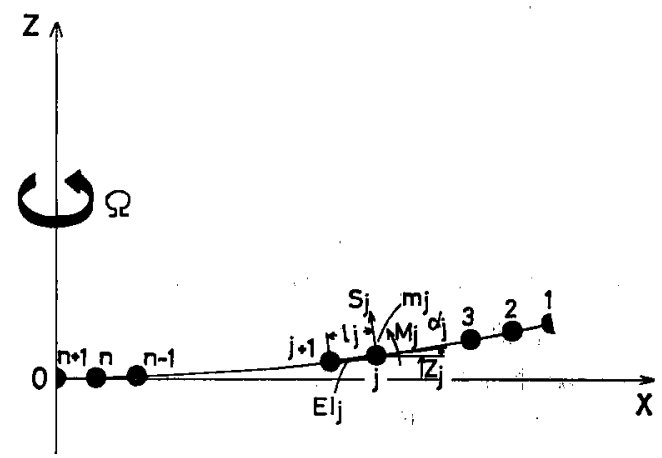

第 2 図 棒の分割と質量の集中

*ただし本報告で不必要な空気力などは省略する。
第 1 図化示すように棒を有限個 $(n)$ 亿分割する。 分割点以番号老つけ；自由端上り順次 $1,2, \cdots \cdots, n, n$ +1 とする. 点 $j$ と $j+1$ で分けられた部分につい

て，勾配 $\alpha$ 己垂直変位 $z$ は次のように表わされる.

$$
\left.\begin{array}{l}
\alpha_{j+1}=\alpha_{j}-S_{j} V_{\alpha S_{j}}-\hat{M}_{j} V_{\alpha M j} \\
z_{j+1}=z_{j}-l_{j} \alpha_{j+1}-S_{j} D_{z} S_{j}-M_{j} D_{z M j} \\
\text { ただし } \quad l_{j} \equiv x_{j}-x_{j+1} \\
V_{\alpha S_{j}}=l_{j}^{2} / 2(E I)_{j}, \quad V_{\alpha \hat{M}_{j}}=l_{j} /(E I)_{j} \\
D z_{S_{j}}=l_{j}{ }^{3} / 3(E I)_{j}, \quad D z_{M j}=l_{j}^{2} / 2(E I)_{j}
\end{array}\right\}
$$

$V_{\alpha S j}, V_{\alpha M j}, D z_{S j}, D z_{M j}$ は影響係数であるが，点 $j$ Ł $j+1$ の間における曲げ剛性の平均值， $(E I)$ ，を用 いて定義される。

式 (1)を(2) へ代入して

$$
z_{j+1}=z_{j}-l_{j} \alpha_{j}+S_{j} V z_{S_{j}}+M_{j} V z_{M j}
$$

ただし

$$
\begin{aligned}
& V_{z} S_{j}=l_{j} V_{r} s_{j}-D_{z} S_{j}=l_{j}{ }^{3} / 6(E I)_{j} \\
& V_{z M_{j}}=l_{j} V_{\alpha M_{j}}-D_{z M_{j}}=l_{j}{ }^{2} / 2(E I)^{\prime}
\end{aligned}
$$

$j, j+1$ 間の質量は 2 分し, 点 $j \_j+1$ に振り分け るむのとする. 汃くして $j$ 点賃量 $m$ ；恓あるるする と,

$$
\begin{aligned}
& \left(f_{x}\right)_{j}=m_{j} x_{j} \Omega^{2} \\
& \left(f_{z}\right)_{j}=-m_{j} \ddot{z}_{j}
\end{aligned}
$$

点 $j+1$ 亿生ずる剪断 $S_{j+1}$ は

$$
\begin{aligned}
S_{j+1} & =\sum_{i=1}^{j}\left[\left(f_{z}\right)_{i} \cos \alpha_{j+1}-\left(f_{x}\right)_{i} \sin \alpha_{j+1}\right] \\
& \cong \sum_{i=1}^{j}\left[\left(f_{z}\right)_{i}-\left(f_{z}\right)_{i} \alpha_{j+1}\right]
\end{aligned}
$$

同様に曲げモーメント $M_{j+1}$ は

$$
M_{j+1}=\sum_{i=1}^{j}\left[\left(f_{z}\right)_{i}\left(x_{i}-x_{j+1}\right)-\left(f_{x}\right)_{i}\left(z_{i}-z_{j+1}\right)\right]
$$

あるいは，

$$
\begin{aligned}
S_{j+1}= & \sum_{i=1}^{j}\left[-m_{i} \ddot{z}_{i}-m_{i} x_{i} \alpha_{j+1} \Omega^{2}\right] \\
M_{j+1}= & \sum_{i=1}^{j}\left[-m_{i} \ddot{z}_{i}\left(x_{i}-x_{j+1}\right)\right. \\
& \left.-m_{i} x_{i} \Omega^{2}\left(z_{i}-z_{j+1}\right)\right]
\end{aligned}
$$

さて，未知の角振動数を $\omega$ とすると，

$$
\begin{aligned}
& z_{j}=\bar{z}_{j} e^{i \omega t}, \quad \alpha_{j}=\bar{\alpha}_{j} e^{i \omega t} \\
& S_{j}=\bar{S}_{j} e^{i \omega t}, \quad \hat{M}_{j}=\bar{M}_{f} e^{i \omega t}
\end{aligned}
$$

と書くことができる.ただし（）は複素振幅を意味 する（共役複素数の意味はない），式(13)を式(1)， (5)，(11)，(12) へ代入すれば,

$$
\begin{aligned}
\bar{\alpha}_{j+1} & =\bar{\alpha}_{j}-\bar{S}_{j} V_{\alpha} s_{j}-\bar{M}_{j} V_{\alpha M j} \\
\bar{z}_{j+1}= & \bar{z}_{j}-l, \bar{\alpha}_{j}+\bar{S}_{j} V_{z} s_{j}+\bar{M}_{j} V_{x M} \\
\bar{S}_{j+1} & =+\sum_{i=1}^{j} m_{i} \omega^{2} \bar{z}_{i}-\bar{\alpha}_{j+1} \sum_{i=1}^{j} m_{i} x_{j} \dot{Q}^{2} \\
\bar{M}_{j+1} & =\sum_{i=1}^{j} m_{i} \omega^{2} \bar{z}_{i}\left(x_{i}-x_{j+1}\right)
\end{aligned}
$$




$$
-\sum_{i=1}^{j} m_{i} x_{i} \Omega^{2}\left(\dot{z}_{i}-\bar{z}_{j+1}\right)
$$

今もし $\bar{\alpha}_{j}, \bar{z}_{j}, \bar{S}_{j}, \bar{M}_{j}$ が既知であるとすれば，(14)， (15) 加ら $\bar{\alpha}_{j+1}, \bar{z}_{j+1}$ が求められ，次いでこれを(16), (17)に入れると $\bar{S}_{j+1}, \bar{M}_{j+1}$ が求められる. したがっ て $\vec{\alpha}_{1}, \bar{z}_{1}, \bar{S}_{1}, \bar{M}_{1}$ が与えられれば，ルートまでの全物 理量が求められる. 先端で境界条件が2つあるから，

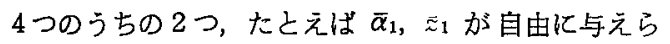
れる、そのとき，あらゆる場所における物理量は $\bar{\alpha}_{1}$ と $\bar{z}_{1} の 1$ 次結合で表わされる.

$$
\bar{\alpha}_{1} \equiv \bar{\varphi}, \quad \bar{z}_{1} \equiv \bar{\delta}
$$

とおくと,

$$
\begin{aligned}
& \bar{\alpha}_{j}=\bar{\varphi} f_{\alpha \phi j}-\bar{\delta} f_{\alpha \delta j} \\
& \bar{z}_{j}=-\bar{\varphi} f_{z_{\varphi j}}+\bar{\delta} f_{z \delta j} \\
& \bar{S}_{j}=-\bar{\varphi} f_{s_{\phi j}}+\bar{\delta} f_{s \delta j} \\
& \bar{M}_{j}=-\bar{\varphi} f_{M \varphi j}+\bar{\delta} f_{M \delta j}
\end{aligned}
$$

ここで $f_{\text {口。口 }}$ は $\omega^{2}$ に依存する. 式 (19) を式 (14) (17)に入れ，両辺の $\bar{\varphi}$ と $\bar{\delta}$ の係数を等圆すると，

$$
\begin{aligned}
& f_{\alpha \square(j+1)}=f_{\alpha \square j}+V_{\alpha S_{j}} f_{S_{\square} j}+V_{\alpha M j} f_{M \square j} \\
& f_{z_{\square}(j+1)}=f z_{\square j}+l_{j j} f_{\alpha \square j}+V_{z S_{j}} f_{S_{\square j}}+V_{Z_{M j}} f_{M_{\square j}} \\
& f s_{\square(j+1)}=\sum_{i=1}^{j+1} m_{i} f_{\mathrm{Z}_{\square}} \omega^{2}+f_{\alpha \square(j+1)} \sum_{i=1}^{j+1} m_{i} x_{i} \Omega^{2} \\
& f_{M \square(j+1)}=\sum_{i=1}^{j+1} m_{i}\left(x_{i}-x_{j+1}\right) f z_{\square} \omega^{2} \\
& -\sum_{i=1}^{j+1} m_{i} x_{i}\left(f z_{\square i}-f z_{\square^{(j+1)}}\right) \Omega^{2}
\end{aligned}
$$

ただし上式で $f$ 添字口中にはまず最初は全て $\varphi$ を入 れる，次いですべてにठを入れる，これらは式(19)中 の $\delta$ の $f_{\text {a吅 }}$ を決定するための溸化式を提供する.

したがって初期值として $j=1$ における $f_{\text {a } 1}$ 值を 与える必要がある. 式(16)，(17)，(18) と(19)より

$$
\begin{aligned}
& \bar{\alpha}_{1}=\bar{\varphi}=\bar{\varphi} f_{\alpha \Phi 1}-\bar{\delta} f_{\alpha \delta 1} \rightarrow f_{\alpha \Phi 1}=1, f_{\alpha \delta 1}=0 \\
& \bar{Z}_{1}=\bar{\delta}=-\bar{\varphi} f_{z_{\boldsymbol{}} 1}+\bar{\delta} f_{\mathrm{z} \delta 1} \rightarrow f \mathrm{z}_{\boldsymbol{\phi} 1}=0, \quad f_{\mathrm{z} \delta 1}=1 \\
& \bar{S}_{1}=m_{1} \bar{Z}_{1} \omega^{2}-\bar{\alpha}_{1} m_{1} x_{1} \Omega^{2}=-\bar{\varphi} m_{1} x_{1} \Omega^{2}+\bar{\delta} m_{1} \omega^{2} \\
& =-\bar{\varphi} f_{s_{\phi 1}}+\bar{\delta} f_{s \delta_{1} \rightarrow} \rightarrow f_{s_{\phi 1}}=m_{1} x_{1} \Omega^{2} \\
& f s_{\delta 1}=m_{1} \omega^{2} \\
& \bar{M}_{1}=0=-\bar{\varphi} f_{M p 1}+\bar{\delta} f_{M \delta 1} \rightarrow f_{M \varphi 1}=f_{M \delta 1}=0
\end{aligned}
$$
結局

$$
\begin{aligned}
& f_{\alpha \Phi 1}=1, f_{\alpha \delta 1}=0 \\
& f_{Z_{\Phi 1}}=0, f_{z \delta 1}=0 \\
& f_{s_{\Phi 1}}=m_{1} x_{1} \Omega^{2}, f s_{81}=m_{1} \omega^{2} \\
& f_{M \Phi 1}=0, f_{M \delta 1}=0
\end{aligned}
$$

$\omega^{2}$ を仮定し式 (24) により初期值を求める. 次いで式 (20)〜（23）により計算を進め，ルートにおりる $f_{\text {口。 }}$ (n+1) K達する. と机を(19)式に入れると $\bar{\alpha}_{n+1}, \bar{Z}_{n+1}$,

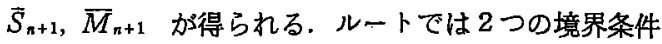
がある.たとえばリジッド支持であれば，

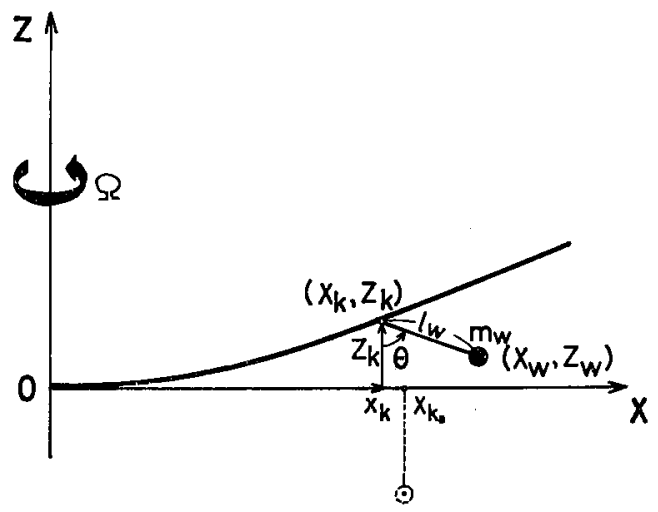

第 3 図 棒につけられた振子とその座標

$$
\bar{\alpha}_{n+1}=\bar{z}_{n+1}=0
$$

これはもしも $\bar{\varphi}, \bar{\delta}$ の両方がゼロでないとき，

$$
\operatorname{Det}\left(\omega^{2}\right)=\left|\begin{array}{cc}
f_{\alpha \Phi(n+1)}, & -f_{\alpha \delta(n+1)} \\
-f_{Z_{\varphi}(n+1)}, & f_{z \delta(n+1)}
\end{array}\right|
$$

の成立を要求する，任意に仮定した $\omega^{2}$ では一般には 式(26)は成立しない，式(26)を成立させるような 求めようとしている固有円振動数である.

\section{4. 振子を加えた HOLZER-MYKLESTAD-LEONE の方法}

4.1 振動数制御振子の運動方程式 振動数制御振 子は、ブレードとその回転軸を含む垂直面内で摇動で きるむのとする，振子の長さを $l_{w}$, 質量を $m_{w} と し$, とれがブレードの静止状態で点 $\left(x_{k 0}, 0\right)$ に取りつけら れているとする.

$0-x_{1} y_{1} z_{1}$ : 空間に固定された座標系

$0-x y z$ : 回転座標系

とすると，

$$
\left(x_{1}, y_{1}, z_{1}\right)^{\imath}=\boldsymbol{A}(x, y, z)^{\imath}
$$

ここた

$$
\begin{aligned}
& ()^{\imath}=\text { マトリクス（）の転換 } \\
& \boldsymbol{A}=\left(\begin{array}{ccc}
\cos \Psi, & -\sin \Psi, & 0 \\
\sin \Psi, & \cos \Psi, & 0 \\
0, & 0, & 1
\end{array}\right)
\end{aligned}
$$

振子の重心を回転座標で表わすと，

$$
\left(\begin{array}{l}
x_{w} \\
y_{w 1} \\
z_{w}
\end{array}\right)=\boldsymbol{r}_{w}=\left(\begin{array}{l}
x_{k 0}+l_{w} \sin \theta-\frac{1}{2} \int_{0}^{x k}\left(\frac{\partial z}{\partial x}\right)^{2} d x \\
0 \\
z_{k}-l_{w} \cos \theta
\end{array}\right) \text { (29) }
$$

よって絶対速度 $\dot{\boldsymbol{r}}_{1 w}$ は,

$$
\dot{\boldsymbol{r}}_{1 w}=\frac{d}{d t}\left(\boldsymbol{A r} \boldsymbol{r}_{w}\right)=\dot{A} \boldsymbol{r}_{w}+\boldsymbol{A} \dot{\boldsymbol{r}}_{w}
$$

絶対速度の 2 乗は

$$
\begin{aligned}
\left|\dot{\boldsymbol{r}}_{1 w}\right|^{2} & =\left(\dot{\boldsymbol{A}}_{w}+\boldsymbol{A} \dot{\boldsymbol{r}}_{w}\right)^{t} \cdot\left(\dot{\boldsymbol{A}} \boldsymbol{r}_{w}+\boldsymbol{A} \dot{\boldsymbol{r}}_{w}\right) \\
& =\dot{\boldsymbol{r}}_{w} \boldsymbol{A}^{t} \boldsymbol{A} \dot{\boldsymbol{r}}_{w}+\boldsymbol{r}_{w}{ }^{t} \dot{\boldsymbol{A}} \boldsymbol{A} \boldsymbol{r}_{w}+2 \boldsymbol{r}_{w} \dot{A}^{i} \boldsymbol{A} \dot{\boldsymbol{r}}_{w}
\end{aligned}
$$




$$
\begin{aligned}
= & \left(\dot{x}_{w}^{2}+\dot{y}_{w}^{2}+\dot{z}_{w}^{2}\right)+\Omega^{2}\left(x_{w}^{2}+y_{w}^{2}\right) \\
& +2 \Omega\left(x_{w} \dot{y}_{w}-y_{w} \dot{x}_{w}\right)
\end{aligned}
$$

しかし $y_{w}=\dot{y}_{w}=0$ だから振子の運動エネルギは，

$$
T_{w}=1 / 2 m_{w}\left|\dot{r}_{1 w}\right|^{2}=1 / 2 m_{w}\left[\left(\dot{x}_{w}^{2}+\dot{z}_{w}{ }^{2}\right)+\Omega^{2} x_{w}{ }^{2}\right]
$$

これから振子に作用する慣性力の $x, \approx$ 成分として，

$$
\left.\begin{array}{l}
-\left[\frac{d}{d t}\left(\frac{\partial T_{w}}{\partial \dot{x}_{w}}\right)-\frac{\partial T_{w}}{\partial x_{w}}\right]=-m_{w} \ddot{x}_{w}+m \Omega^{2}{ }_{w} \\
-\left[\frac{d}{d t}\left(\frac{\partial T_{w}}{\partial \dot{z}_{w}}\right)-\frac{\partial T_{w}}{\partial z_{w}}\right]=-m_{w} \ddot{z}_{w}
\end{array}\right\}
$$

したがって振子がブレードに及ぼす慣性力を $\Delta f_{x}, \Delta$ $f=$ 上すると

$$
\begin{aligned}
\Delta f_{x} & =-m_{w}\left(\ddot{x}_{w}-\Omega^{2} x_{w}\right) \\
& =-m_{w}\left[l_{w} \ddot{\theta} \cos \theta-\Omega^{2}\left(x_{k 0}+l_{w} \sin \theta\right)\right] \\
\Delta f_{z} & =-m \ddot{z}_{w}=-m_{w}\left(\ddot{z}_{k}+l_{w} \ddot{\theta}_{\sin } \sin \theta\right.
\end{aligned}
$$

$\Delta f_{x}$ 中で $-\frac{1}{2} \int_{0}^{x k}\left(\frac{\partial z}{\partial x}\right)^{2} d x$ は 2 次の微小量なので省 略できる.

次に振子 $\sigma \theta$-自由度運動方程式を導びく.とれは重 カポテンシァル $U_{w}=m_{w} z_{w} g$ をあ考え LAGRANGE 運動方程式汃ら求める.

$$
\begin{aligned}
T_{w}= & \frac{1}{2} m_{w}\left[\left(l_{w} \dot{\theta} \cos \theta-\frac{d}{d t} \frac{1}{2} \int_{0}^{x_{k}}\left(\frac{\partial z}{\partial x}\right)^{2} d x\right)^{2}\right. \\
& +\left(\dot{z}_{k}+l_{w w} \dot{\theta} \sin \theta\right)^{2}+\Omega^{2}\left(x_{k 0}+l_{w} \sin \theta\right. \\
& \left.\left.-\frac{1}{2} \int_{0}^{x_{k}}\left(\frac{\partial z}{\partial x}\right)^{2} d x\right)^{2}\right] \\
U_{w}= & m_{w} g\left(z_{k}-l_{w} \cos \theta\right)
\end{aligned}
$$

とれから

$$
\left[\frac{d}{d t} \frac{\partial}{\partial \dot{\theta}}-\frac{\partial}{\partial \theta}\right]\left(T_{w}-U_{w}\right)=0
$$

をつくると

$$
\begin{gathered}
m_{w} l_{w}\left[l_{w} \ddot{\theta}+\ddot{z}_{k} \sin \theta-\Omega^{2}\left(x_{k 0}+l_{w} \sin \theta\right) \cos \theta\right. \\
+g \sin \theta]=0
\end{gathered}
$$

振子の平衡位置 $\theta_{0}$ は

$$
\tan \theta_{0}=\frac{\Omega^{2}}{g}\left(x_{k 0}+l_{w} \sin \theta_{0}\right)
$$

で与えられる. $\theta$ の $\theta_{0}$ まわりの微小䚐乱 $\Delta \theta$ を求め る. $\Delta \theta$ の 2 次以上を無視すると

$$
l_{w}(\Delta \ddot{\theta})+\Omega^{2}\left\{\frac{x_{k}}{\sin \theta_{0}}+l_{w} \sin ^{2} \theta_{0}\right\} \Delta \theta+\ddot{z}_{k} \sin \theta_{0}=0
$$

との式を $\Delta \theta$ に関する強制振動の式と見なす.

$$
\Delta \theta=\overline{\Delta \theta} e^{i \omega t}, \quad z_{k}=\bar{z}_{k} e^{i \omega t}
$$

$$
\text { とおくと }
$$

$$
\begin{aligned}
& \overline{\Delta \theta}=l_{w} \frac{\bar{z}_{k} \sin \theta_{0}}{\left(\frac{\omega_{w}^{2}}{\omega^{2}}-1\right)} \\
& \omega_{w}{ }^{2} \equiv \Omega^{2}\left(\sin ^{2} \theta_{0}+\frac{x_{k 0}}{l_{w}}-\frac{1}{\sin \theta_{0}}\right)
\end{aligned}
$$

\section{2 振子を含むよう拡張された HML 法}

\section{2 .1 振動数制御振子を含む基本関係式 との場}

合，式(7)，(8)で与えられる $f_{x}, f_{x}$ には式(34),

(35)による修正が必要である，すなわち，

$$
\left(f_{x}\right)_{j}=m_{j} x_{j} \Omega^{2}-\delta\left(x_{j}, x_{k}\right) m_{w}\left[l_{w} \ddot{\theta} \cos \theta\right.
$$

$$
\left.-\Omega^{2}\left(x_{k 0}+l_{w} \sin \theta\right)\right]
$$

$\left(f_{s}\right)_{j}=-m_{j} \ddot{z}_{j}-\delta\left(x_{j}, x_{k}\right) m_{w}\left(\ddot{z}_{k}+l_{w} \ddot{\theta}_{\sin } \theta\right)$

ことで

$$
\delta\left(x_{j}, x_{k}\right)=\left\{\begin{array}{lll}
1, & x_{j}=x_{k} & \text { のटき } \\
0, & x_{j} \neq x_{k} \text { のとき }
\end{array}\right.
$$

ところが式(9)，(10)を見てわかるように， $f_{x}$ には 一次微小量が乗ぜられる，よって式(43)中の してよい. 結局

$$
\begin{aligned}
& \left(f_{x}\right)_{j}=m_{x j} x_{j} \Omega^{2} \\
& \left(f_{x}\right)_{j}=m_{z j} z_{j} \omega^{2}
\end{aligned}
$$

ただし

$$
\begin{aligned}
& m_{x j} \equiv m_{j}+\delta\left(x_{j}, x_{k}\right) m_{w}\left(1+\frac{l_{w}}{x_{k}} \sin \theta_{0}\right) \\
& m_{z j} \equiv m_{j}+\delta\left(x_{j}, x_{k}\right) m_{w}\left(1+\frac{\sin ^{2} \theta_{0}}{\left(\frac{\omega_{w}}{\omega}\right)^{2}-1}\right)
\end{aligned}
$$

あしむ $\omega \cong \omega_{w}$ であれば $m_{z}\left(x=x_{k}\right)$ は非常に大きく なる. したがって固有振動数は著しく変化するである うと期待される.これが掁動数制御振子のねらいであ 万.

第3 節で迹べた本来の HML 法は， $m_{j}$ の代わり に，式(47)，(48)で定義された $m_{x j}, m_{x j}$ を用いるこ と以外，全く変わらない，したがって，式(20)，(21) は不変, 式(22)，(23)は次のようになる;

$$
\begin{aligned}
f_{S_{\square}(j+1)}= & \sum_{i=1}^{j+1} m_{z i} f_{\mathrm{Z}_{\square}} \omega^{2}+f_{\alpha_{\square}(j+1)} \sum_{i=1}^{j+1} m_{x i} x_{i} \Omega^{2} \\
f_{M_{\square}(j+1)}= & \sum_{i=1}^{j} m_{z i}\left(x_{i}-x_{j+1}\right) f_{z \square i} \omega^{2} \\
& -\sum_{i=1}^{j+1} m_{x i} x_{i}\left(f_{z \square i}-f_{z \square(j+1)}\right) \Omega^{2}
\end{aligned}
$$

また式(24)に和いて $f_{s p 1,} f_{s \delta 1}$ のみは次のように改め られる。

$$
f_{s థ 1}=m_{x 1} x_{1} \Omega^{2}, f_{s 81}=m_{z 1} \omega^{2}
$$

4.2.2 数値計算の方法 数值計算の方法は第 3 節 の終わりで述べたあの亡変わらない，すなわち，ある 適当に小さい $\omega^{2}$ から計算を始めだんだん増してゆく． 各 $\omega^{2}$ そついて，式(26)で与えられる $\operatorname{Det}\left(\omega^{2}\right)$ が得ら れる. この $\operatorname{Det}\left(\omega^{2}\right)$ の絶対值が十分に小さくなるよう な $\omega^{2}$ の值, $\omega_{1}{ }^{2}, \omega_{2}{ }^{2}, \omega_{3}^{2}, \cdots \cdots$ を

$$
\omega_{1}^{2}<\omega_{2}^{2}<\omega_{3}^{2}<\cdots \cdots \cdots \cdots
$$

の順に並べる． $\omega_{1}, \omega_{2}, \omega_{3}, \cdots \cdots$ はそれぞれ第 $1,2,3, \cdots$ …次の固有振動数である. 
4.2 .3 選ばれた計算例 母体としてのブレードは 一様とした. しかし用いられたコンピュータ・プログ ラムを実際のヘリコプタ・ブレードのような非一様な 場合へ変更するてとはきわぬて容易である.

またルートは回転中心片持ち梁として取りつけら れているとした.これをたとえばフラッピング・ヒン ジ・オフセットのある場合へ変更するとと屯簡単であ る.

計算 case は,

(1)まず振子なし，非回転の場合について，分割数 を変じて計算し，詥差が十分小さくなる分割数を 探索する.

(2) 次いで，(1)で選ばれた適当な分割数を用いて回 転中の固有振動数を求める. 計算は次の各場合に ついて行なう；

母体ブレード

単に 1 質量を付加されたブレード

振子つきブレード

後の $2 つ$ 場合，質量または振子の取りつけ位置変化 の効果，母体ブレードに対する質量比変化の効果を調 ベる. 振子の非連成固有振動数 $\omega_{w} は$ ，母体ブレード の回転時の 2 次曲げ固有振動数に等しく選んだ.

\section{5. 計 算 結 果}

\section{1 本計算に用いられた基本常数}

次の值を用いた；

$$
\begin{aligned}
& g=9.80665 \mathrm{~m} / \mathrm{sec}^{2} \\
& l t=4 \mathrm{~m} \\
& g / l t=2.45166 / \mathrm{sec}^{2} \\
& \rho A l t^{4} / E I=0.299516 \mathrm{sec}^{2}
\end{aligned}
$$

5.2 ブレード分割数之計算精度の関係 ブレード 分割数之計算精度の関係を調べるため，回転のない一 様片持ち梁について, 分割数を変えて計算を行なっ た. 分割の方法は等分割. 厳密解析解々の比較より, 第 4 図に示す分㓶数之誤差の関係を得た。われわれ は，以後の計算に拈いては合理的分割数 $n=50$ を用 いるととにした.

5.3 設計振動数の決定 一様棒に回転を与えたと きの固有振動数を計算し，第 5 四の結果を得た。これ をみると，2次の固有円振動数と $3 \Omega$ が次の值におい て一致している.

$$
\begin{aligned}
\tilde{\Omega} & =13.812 \\
\tilde{w}_{2}=3 \tilde{\Omega} & =41.44
\end{aligned}
$$

この回転角速度における掁動のモード形状の計算結果 を第 6 図に示す.

5.4 単純付加質量の勏果 炊に振子の勃果之比較 するため，単純付加質量を 1 個つけた場合を計算し
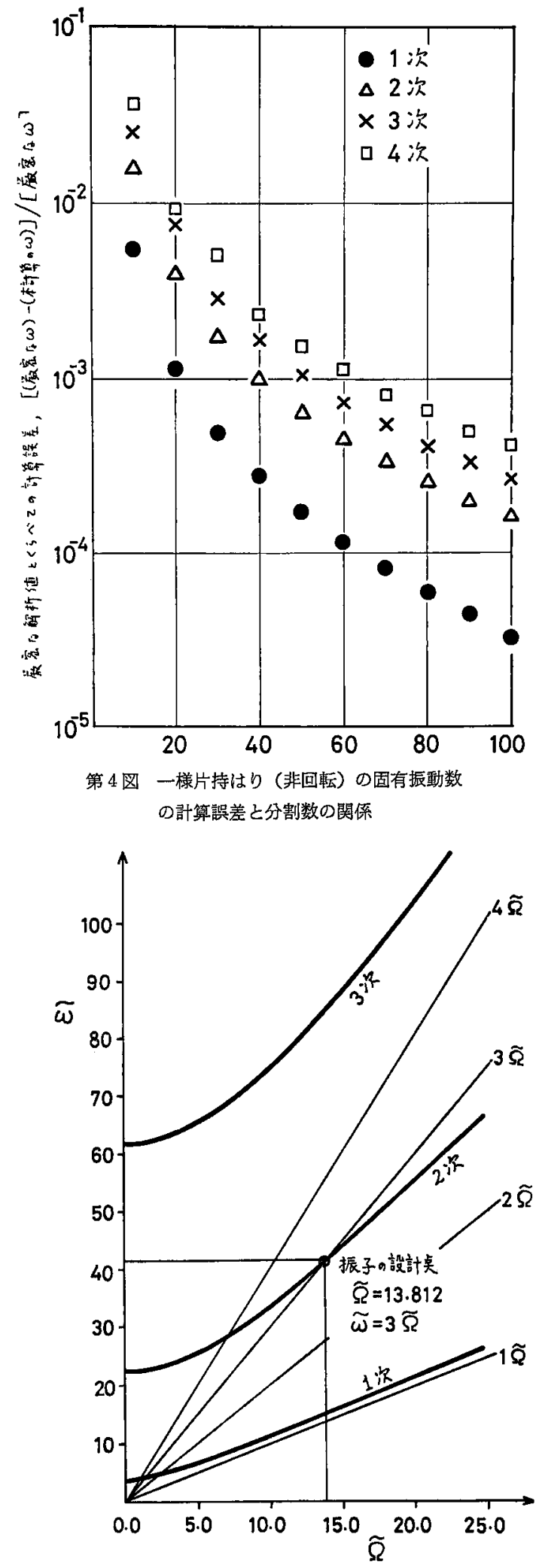

第 5 図 付加物なし，一様ブレードの $\tilde{\omega}$ vs $\tilde{8}$ 


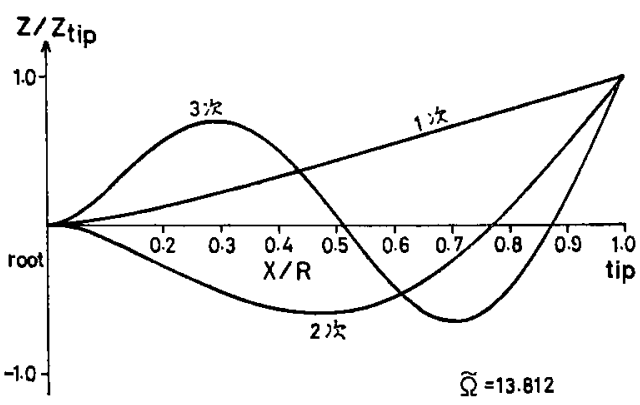

第 6 図 付加物なし，一様ブレードのモード形状

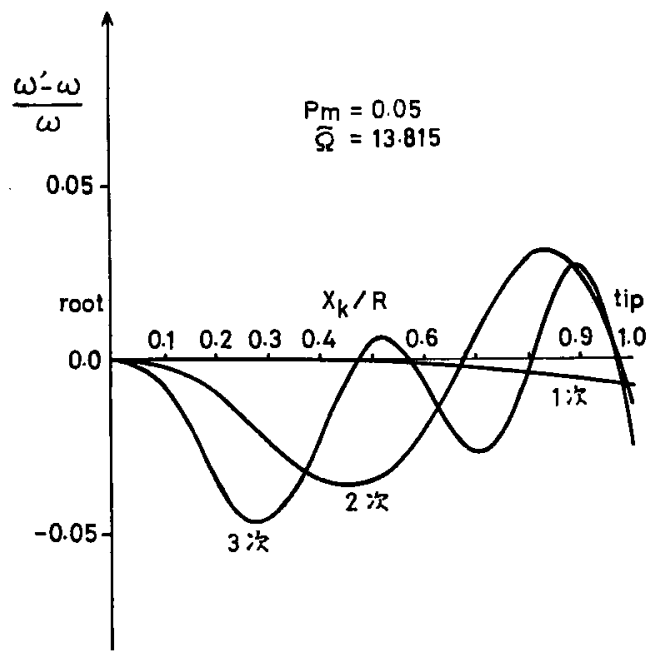

第 7 図 付加質量の取り付け位题による，振動数の变化 の、の'はそれぞれ付加質屋の取り付け前後の振動数

た. 第 7 図には $\tilde{\Omega}=13.812$ で $5 \%$ 質量比の付加質量 の取り付け位置を変化した場合の計算結果を示す。こ れによって，振動の節に付加質量があるときは，遠心 力硬化作用* のため，振動数が高くなるが，腹に取り 付けたときは，硬化作用にまさる慣性効果のため，振 動数が低下する現象が見いだされた。

\section{5 振子の効果}

（1）“基準条件（設計点）”での効果

本報告では，次の值を，便宜上基準条件とする**.

$$
\begin{aligned}
& x_{k}=0.22 l t, \quad p_{m}=0.05 \\
& \tilde{\omega}_{w}=41.44=3 \tilde{\Omega} \\
& \widetilde{\Omega}=13.812
\end{aligned}
$$

乙の場合に，固有振動数の変化率， $p_{k} ， \theta_{0}$ K関して 次の值を得た。

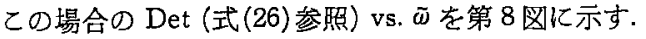
比較のためにまた付加物なし一様ブレードのそれる含

* 一般に棒の軲方向に加えられた張力（任縮力）は曲げの 固有振動数を上（下）げる．したがって遠心力そのもの は固有振動数を增大させる，

** 常用回転数 $\Omega=13.812$ で, $\omega_{2}$ 々 $3 \widetilde{\Omega}$ が一致した場合 を想定している.

\begin{tabular}{ll|c|c}
\hline & & 固有円振軦数 $\left(\tilde{\omega^{\prime}}\right)$ & 変化率 $\left(\frac{\omega^{\prime}-\dot{\omega}}{\omega}\right)$ \\
\hline 1 & 次 & 14.967 & -0.0002635 \\
2 & 次 $(-)$ & 38.006 & -0.08281 \\
2 & 次 $(+)$ & 44.450 & 0.07270 \\
3 & 次 & 85.716 & 0.01232 \\
\hline
\end{tabular}

$p_{I}=0.0275, \theta_{0}=89.11$ (degree)

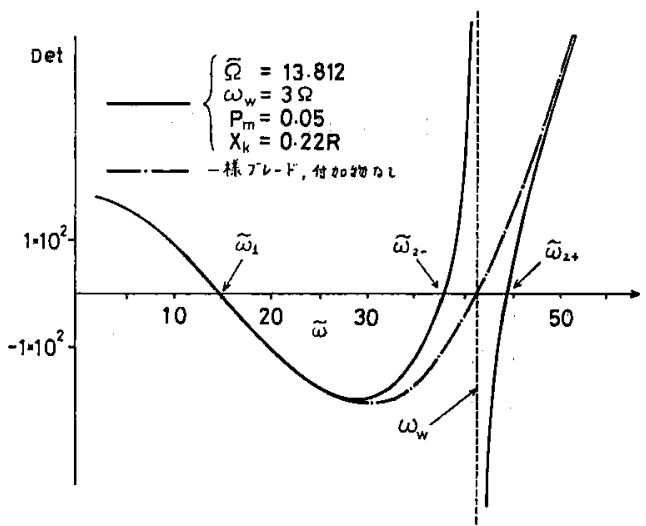

第 8 図振子つきの Det vs. $\tilde{\omega}$ の一例

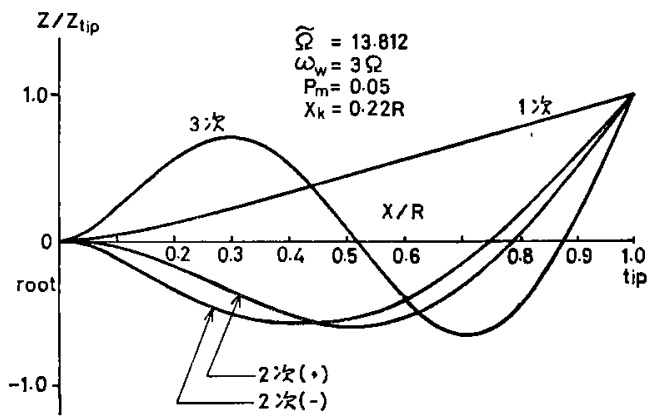

第 9 図振子つきブレードのモード, 形状

まれている.振子の固有振動数を，付加物なしの 2 次 の固有振動数に合わせることによって，2次の固有振 動数は 2 個に分解する.モード形状を第 9 図に示す.

(2) 種々のパラメターの效果

振子の取り付け位置 $x_{k}$ のみを変化させ，第10図 に示す結果をえた。と机より振動の腹につけた場合が 効果的で，節につけた場合は，効果がほとんどなくな るととがわかる.また，2次の振動数について，単純 付加質量との比較を，第11図で示す．これより，振子 の方が単純付加質量より效果的であるととがわかる。

一振子の質量比のみを変化させる計算を行ない，第 12図に示す結果を得た．振子の質億が小さい場合，質 量の僅汃の增大む非常に効果的であるが，反面むやみ 敒量を増大してあ，意味がないてとがわかる。

一 $\omega_{w}$ のみを変化する計算を行ない，第13 図に示す 結果を得た． 2 次 $(+) ， 2$ 次(一)双方ともが付加物な 

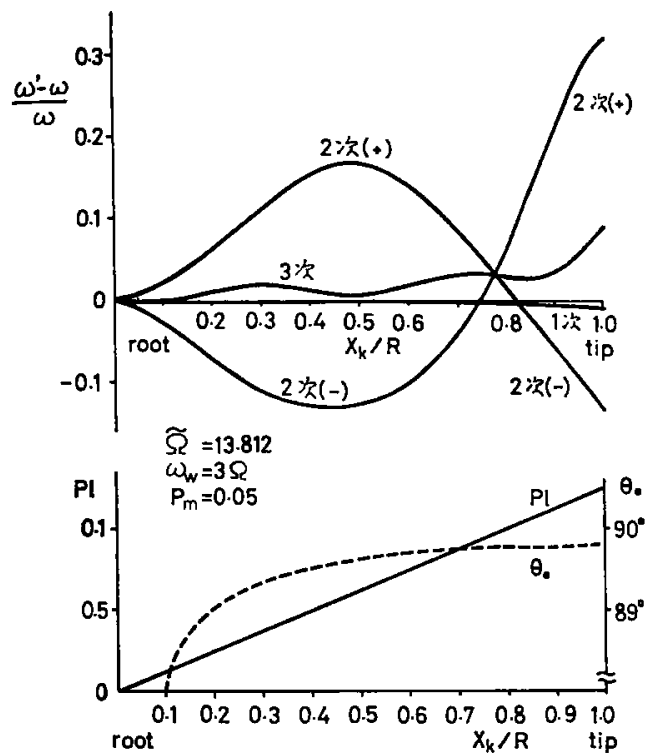

第10図 振子取りつけ位置による変化

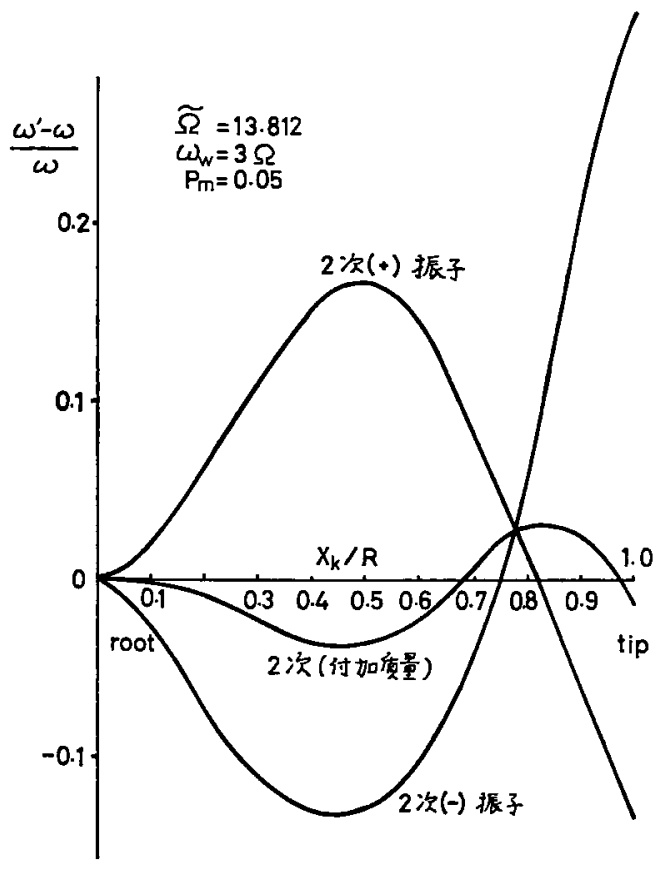

第11区 振子と付加質量の効果の比较

しの 2 次の振動数から，離れるべきであるという見解 加ら，同図（b）のように書きあらためた．本図より 付加物なしの 2 次の固有掁動数に非常に近い $\omega_{\text {w }}$ にお いて，振子の効果か゚ピークをなすととがわかる.

一最後化“基準条件”のうち

$x_{k}=0.22 l t$

$p_{l}=0.0275, p_{m}=0.05$

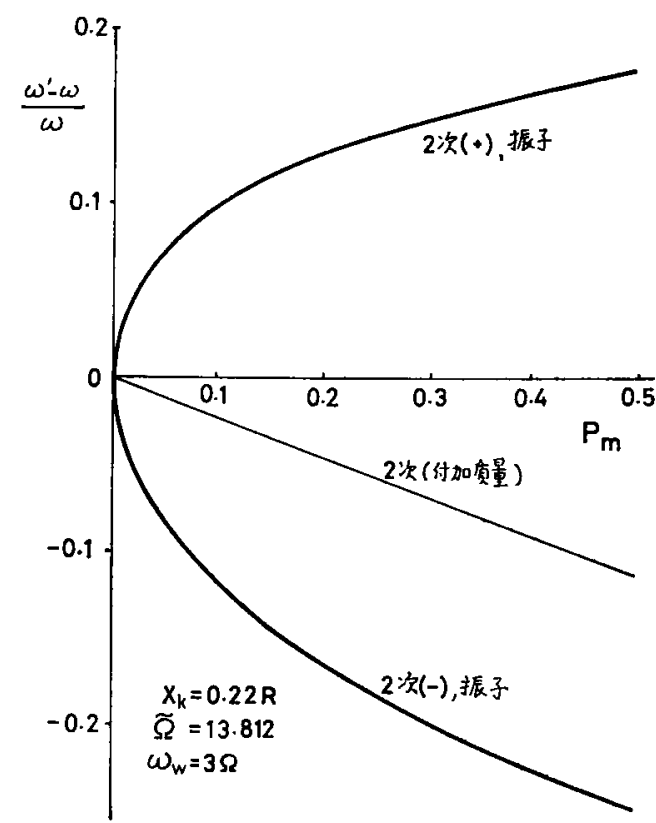

第12図振子およひ付加罆量への質量化の効果

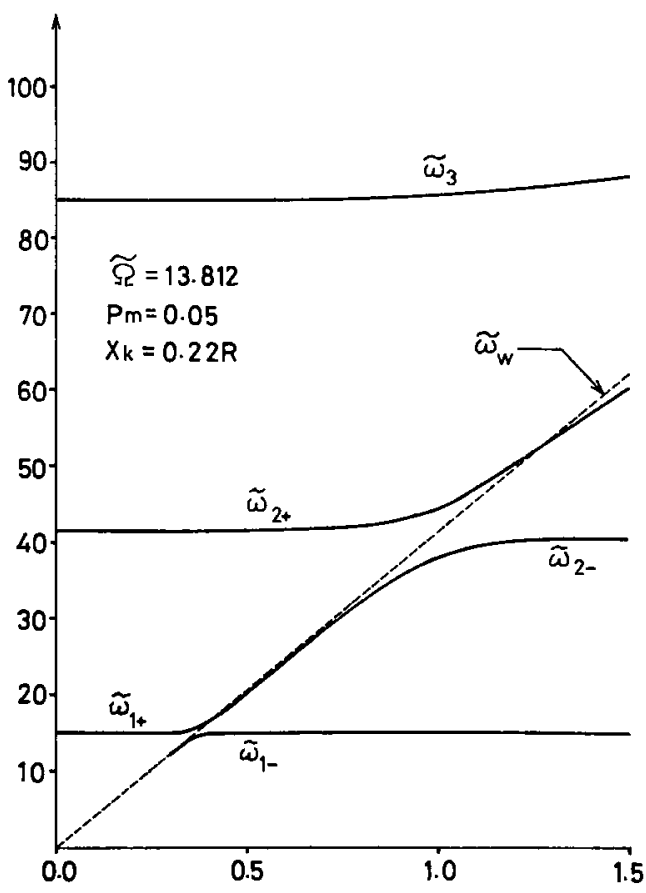

第13図（a）振子の固有振動数 $\omega_{v}$ の効果（その1）

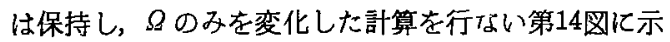
す結果を得た. 2 次 $(+)$ と $3 \Omega$ の交点は，現われず， 2 次 $(-)$ と $3 \Omega$ の交又点は大幅に回転角速度の娍少し たところに移動している.乙れは振子が，常用回転数 での, 固有円振動数之，回転角速度の整数倍の一致を 防ぐのに，有効な手段であるととを示している. 


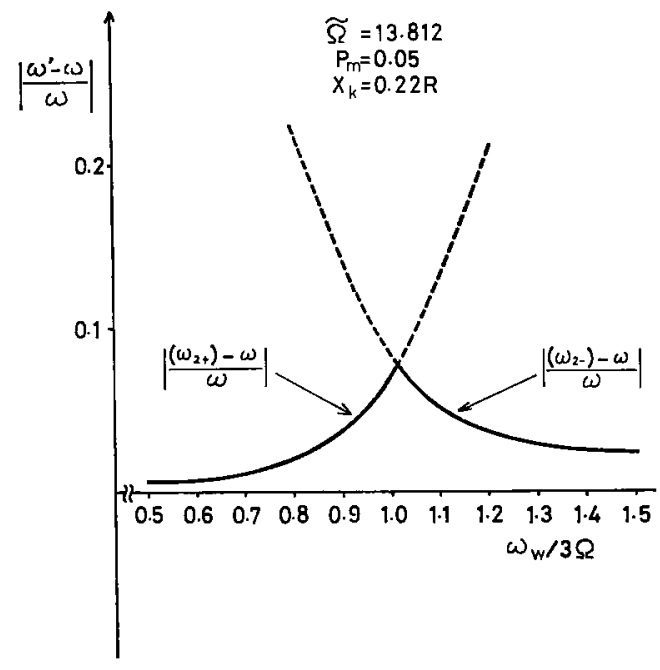

第13図（b） $\omega_{w}$ Kよる 2 次振動数の変化の絶対值

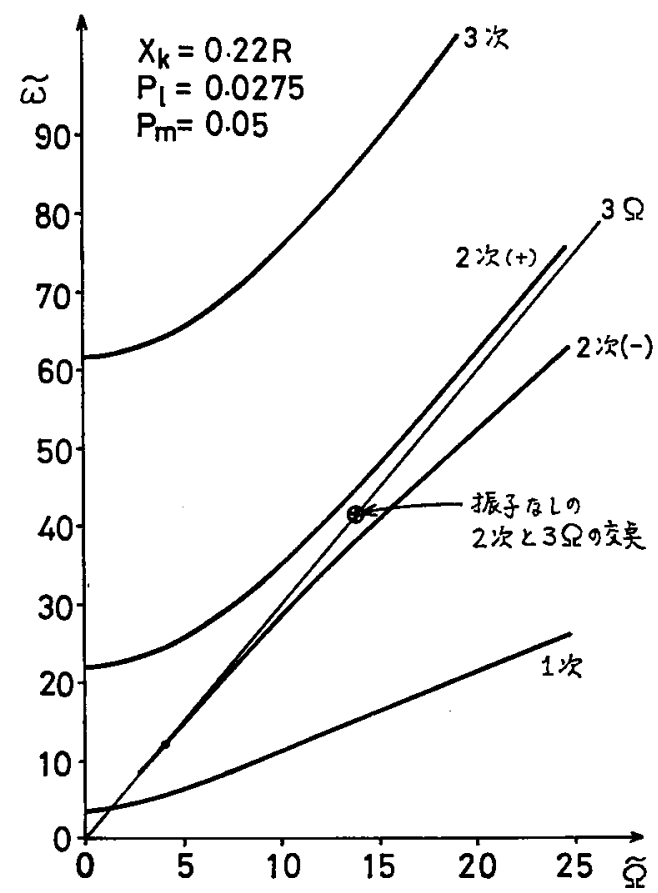

第14図 振子つきの場合の $\tilde{\omega}$ vs. $\tilde{\Omega}$
5.6 計算時間 最後に，本計算のため，名古屋大 学 FACOM 230-60 を使用した. 計算時間は， 1 次, 2 次 $(-), 2$ 次 $(+), 3$ 次の固有振動数をうるのに約 10秒を要する程度である.

\section{6. 結 論}

ヘリコプタ・ロータのブレードの理想化されたむの として，回転軸に垂直にリジッドに取りつけられた一 様棒を考えた. これのフラッピングの固有振動数をず らせる手段として FRAHM の動吸振器（振子）が効果 的であるととを示すために，いくらかの計算を行なっ た. その結果,

（1）振子の効果を最大にするためには，その固有 振動数を, 振子付加前のブレードの固有振動数の近く におく必要がある.

（2） 1 つの振子は 1 つの振動数の変更に対しての み有効で，その振動数を2つに分解する.

（3）振子取りつけ位置に関しては振動形の節より 遠いところが效果的である，節につけると単純付加質 量と同じとなり，かつ遠心力硬化作用のみを呈する.

（4）振子とブレードの質量化に関しては，さほど 大きい値を必要としない，一方単純付加質量の効果は ほぼ質量比に比例するので，小さい質量比では前者は 後者の数倍の効果を呈する.

謝辞: 本研究の発表に対し，種々ので好意ある配慮な らびに有益なご教示を睗わった川崎重工航空機事業部 の高島勢記部長に厚くお礼申し上げます。

\section{参考文 献}

1) LвoNE, P. F.; "Theory of Rotor Blade Uncọipled Flap Bending Aero-Elastic Vibrations", Presented at The 10th. Annual National Forum of The American Helicopter Society, 1954.

2) Den Hartog, J. P.; "Mechanical Vibrations", Mc Graw-Hill, New York, 1956, p. 87 91.

3）永津备介：“リシッド・ロータ・ヘリエプタの国産開 発飞ついて, “日本航空宇宙学会誌, 第19巻，第207号， 1971.

4）航空情報, 1968年 9 月, p. 16 17

\section{太陽帆を用いた宇宙船の軌道特性と最適操舵* \\ Orbital Characteristics of Solar Sailers}

\section{松 尾 弘 毅** \\ Hiroki Marsuo}

\footnotetext{
* 昭和47年11月14日 原稿受理

** 東京大学宇宙航空研究所
}

\section{Abstract}

Trajectories of the solar sailers which fall inward to the sun, starting from the earth orbit, 